Japan. J. Med. Sci. Biol., 34, 281-291, 1981

\title{
ACUTE EFFECTS OF CADMIUM ON DELAYED-TYPE HYPERSENSITIVITY IN MICE*
}

\author{
Asato KOJIMA and Shin-IChi TAMURA \\ Department of Pathology, National Institute of Health, \\ Kamiosaki, Shinagawa-ku, Tokyo 141
}

(Received June 5, 1981. Accepted July 31, 1981)

\begin{abstract}
SUMMARY: A single exposure of mice to cadmium resulted in suppression of the induction of primary delayed-type hypersensitivity (DTH) responses as well as memory T-cell and suppressor T-cell activities, augmenting and inhibiting DTH respectively. Furthermore, cadmium suppressed the expression of already established DTH, in immune mice, even though DTH-effector T cells in the spleen of immune mice were not affected by cadmium injeciton. Such suppressive effects were demonstrated when cadmium was administered within 2 days before immunization or elicitation for DTH. Cadmium caused also within 2 days in mice thymic involution and splenomegaly.

These results indicate that cadmium inhibits not only the generation of certain populations of $\mathrm{T}$ lymphocytes for DTH but also some mechanisms in the host involved in the expression of DTH.
\end{abstract}

\section{INTRODUCTION}

Cadmium (Cd), an environmental contaminant, has in animals acute and chronic physiological effects (Christensen and Olsen, 1957; Flick, Kraybill and Dimitroff, 1971). The pollutant has been demonstrated to be favorable to infectious agents in animals (Koller, 1973; Exon, Koller and Kerkvliet, 1979), suggesting that it modulates the immune system of the host. In antibody responses, it was reported that prolonged exposure to $\mathrm{Cd}$ resulted in reduced antibody synthesis to various antigenic stimulation (Koller, 1973; Koller, Exon and Roan, 1975). Furthermore, studies by Jones, Williams and Jones (1971) demonstrated that a single dose of Cd altered circulating antibody titers depending upon the time of antigen inoculation. More recently, it was also reported that antibody responses to an antigen decreased when Cd was given orally (Koller, Exon and Roan, 1976) but increased when injected intraperitoneally (Koller et al., 1976; Suzuki et al., 1981). On the other hand, little is understood about acute and chronic effects of $\mathrm{Cd}$ on cell-mediated immunity.

\footnotetext{
* This study was supported in part by Grant-in-Aid for Environmental Science from the Environment Agency. 小島朝人 - 田村慎一（国立予防衛生研究所 病理部）
} 
The purpose of the present study is to see the acute effects of $\mathrm{Cd}$ on T-cellmediated immunity, delayed-type hypersensitivity (DTH), against ovalbumin (OA) in mice, on which effects of chronic low-level exposure to Cd on T-cell responses may be discussed. In the experiments, DTH-effector T-cell activity, and memory $T$-cell and suppressor $T$-cell activities augmenting and inhibiting DTH responses, respectively (Kojima, Tamura and Egashira, 1979a,b; Tamura, Kojima and Egashira, 1980, 1981), were investigated in mice given a single dose of $\mathrm{Cd}$ which produced no overt decrease in body weight gains or no deaths in a 10 -week period.

\section{Materials ANd Methods}

Mice: Female $(\mathrm{C} 57 \mathrm{BL} / 6 \times \mathrm{DBA} / 2) \mathrm{F}_{1}$ mice were obtained from the Shizuoka Agricultural Cooperative Association for Laboratory Animals, Hamamatsu-shi, Japan. All mice were 12-16 weeks of age when the experiments were initiated.

Antigens: Ovalbumin (OA) recrystallized five times was purchased from Seikagaku Kogyo Co., Ltd., Tokyo. Reduced and alkylated OA (RA-OA) was prepared by reducing $\mathrm{OA}$ with $0.05 \mathrm{M}$ 2-mercaptoethanol in $8 \mathrm{M}$ urea at room temperature overnight and then alkylating it with $0.1 \mathrm{M}$ iodoacetamide at $4 \mathrm{C}$ for $1 \mathrm{hr}$ (Kojima et al., 1979b). OA and RA-OA, dissolved in $0.1 \mathrm{M}$ Tris-HCl buffer ( $\mathrm{pH} 8.0$ ), were purified by gel filtration through a Sephadex G-100 column. The purified $\mathrm{OA}$ and RA-OA were dialyzed against borate-buffered saline $(\mathrm{pH} 8.0)$ and used in the experiments.

Cadmium administration: Groups containing 5 or 10 mice were injected intraperitoneally a single dose of $0.75 \mathrm{mg} / \mathrm{kg}$ or $6 \mathrm{mg} / \mathrm{kg}$ of cadmium chloride (Cd) in $0.9 \% \mathrm{NaCl}$. Control mice were given $0.9 \% \mathrm{NaCl}$.

Sensitization: For the induction of a DTH response against OA, mice were immunized subcutaneously with $10 \mu \mathrm{g}$ of OA absorbed by $100 \mu \mathrm{g}$ of aluminium hydroxyde gel (alum). The memory T-cell activity for DTH against OA, which was manifested by the acceleration of the DTH response (Kojima et al., 1979a) was induced in mice by priming subcutaneously with $1 \mu \mathrm{g}$ of RA-OA 7 days before immunization with $\mathrm{OA}$ in alum. It was determined on Day 4 after immunization (Tamura et al., 1981). For the induction of the suppressor T-cell activity, mice were primed intravenously with $500 \mu \mathrm{g}$ of RA-OA. Primed mice were immunized 7 days later with $\mathrm{OA}$ in alum and their suppressive activity was determined on Day 7 after immunization (Kojima et al., 1979a; Tamura et al., 1980).

Assay for DTH: OA-specific DTH was elicited in mice by a challenge injection with $10 \mu \mathrm{g}$ of $\mathrm{OA}$ absorbed by $20 \mu \mathrm{g}$ of alum into the right-hind footpad (Kojima et al., 1979a). As a control, $20 \mu \mathrm{g}$ of alum was injected into the left-hind footpad. DTH was determined from the increase in footpad thickness $24 \mathrm{hr}$ after the challenge injection and expressed in 0.01-mm units (Tamura et al., 1973).

Assay for DTH-effector cells: The effector T-cell activity for DTH in the 
spleen cells from immune mice was assessed in local transfer experiments. Thus, the spleen cell suspension was prepared in a balanced salt solution. Viable spleen cells $\left(1.2 \times 10^{7}\right)$ were injected into the right-hind footpad of normal mice along with $50 \mu \mathrm{g}$ of $\mathrm{OA}$ absorbed by $50 \mu \mathrm{g}$ of alum. As a negative control, normal spleen cells were injected with the same doses of $\mathrm{OA}$ and alum. The increase in footpad thickness in recipient mice was measured $24 \mathrm{hr}$ later as the index of the DTH-effector cell activity (Kojima et al., 1979b).

Assay for antibody: Antibody titers against $\mathrm{OA}$ in duplicate pooled sera from each group of mice were determined by passive hemagglutination with sheep red blood cells coated with OA by the chromium chloride methods (Kojima et al., 1979a; Tamura et al., 1973). The results were expressed as a mean $\log _{2}$ titer and mean differences of \pm 2 or more were considered significant.

Statistical analysis: Statistical analysis was carried out by Student's $t$ test. Mean differences were considered significant when $p<0.05$.

\section{Results}

\section{Suppression of Induction and Expression of DTH by Cadmium}

Effects of Cd doses on primary DTH and antibody responses were examined in the initial experiments. Groups of 15 mice were injected intraperitoneally with various doses $(0.75-6.0 \mathrm{mg} / \mathrm{kg})$ of Cd simultaneously with sc immunization with $\mathrm{OA}$ in alum. An additional group of 15 mice were given saline and then immunized with $\mathrm{OA}$ in alum as controls. Five mice from each group were tested for DTH against OA on Day 7 and for anti-OA antibody titers on Days 7 and 14. Table I demonstrates that neither DTH responses nor antibody titers in groups of mice given $\mathrm{Cd}$ simultaneously with immunization were sig-

TABLE I

Effects of Cd dose on primary DTH and antibody response against $O A^{a)}$

\begin{tabular}{cccc}
\hline \multirow{2}{*}{$\begin{array}{c}\text { Cadmium dose } \\
(\mathrm{mg} / \mathrm{kg})\end{array}$} & $\begin{array}{c}\text { Footpad swelling } \\
(0.01 \mathrm{~mm})\end{array}$ & \multicolumn{2}{c}{ Antibody titer $\left(\log _{2}\right)^{c)}$} \\
\cline { 3 - 4 } & & Day 7 & Day 14 \\
\hline- & $43.8 \pm 6.0$ & 4.0 & 6.0 \\
0.75 & $63.0 \pm 10.7$ & 4.0 & 7.5 \\
1.5 & $59.4 \pm 9.7$ & 4.0 & 7.0 \\
3.0 & $41.0 \pm 6.2$ & 3.5 & 6.5 \\
6.0 & $40.2 \pm 10.6$ & 3.0 & 7.0 \\
\hline
\end{tabular}

a) Mice were injected intraperitoneally with various doses of $\mathrm{Cd}$ and immunized subcutaneously with $10 \mu \mathrm{g}$ of $\mathrm{OA}$ in alum on Day 0 .

b) DTH was tested on Day 7 after immunization. Each value represents the mean footpad swelling for groups of 5 mice \pm S.E.

c) Pooled sera from groups of five mice were titrated in duplicate. Each value represents the mean $\log _{2}$ titer. 


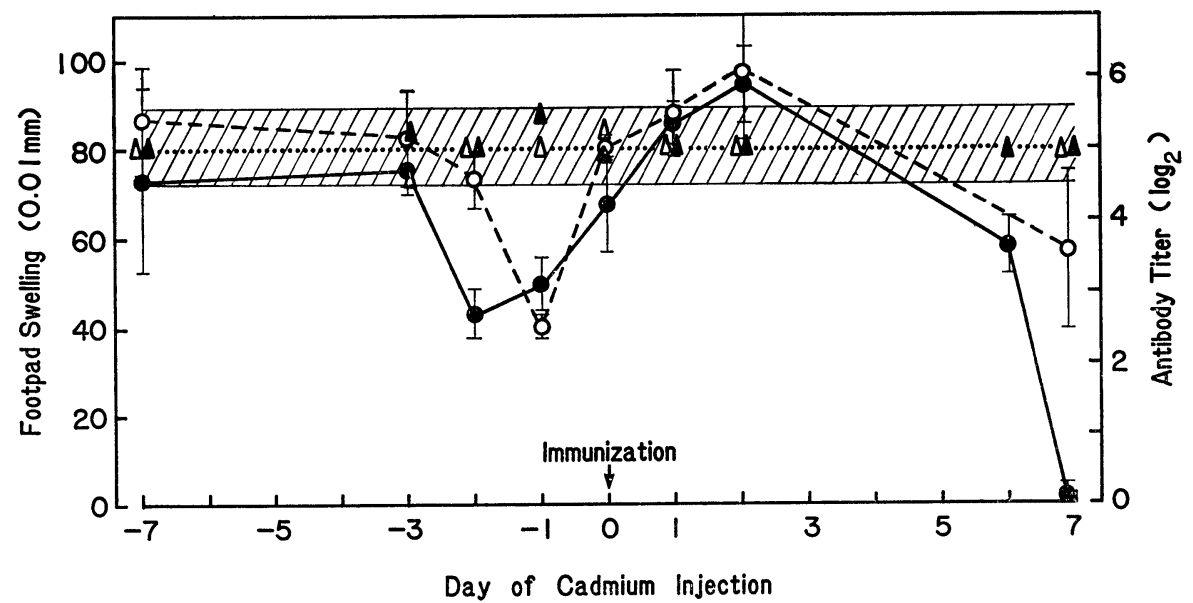

Fig. 1. Effects of Cd administration at different intervals in relation to time of immunization. Mice were given a single ip dose of $0.75 \mathrm{mg} / \mathrm{kg}$ or $6 \mathrm{mg} / \mathrm{kg}$ of Cd 1-7 days before (designated as minus days) or 1-7 days after immunization on Day 0 with $10 \mu \mathrm{g}$ of OA in alum. Control mice were given saline on Day 0 . All mice were tested for DTH against $\mathrm{OA}$ on Day 7. Results shown are means ( \pm S.E.) of footpad swelling in groups of 5 mice

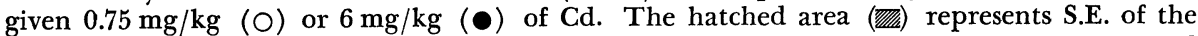
mean of the control group of 5 mice. Sera were taken immediately after measuring footpad swelling and pooled sera were titrated in duplicate. Each value represents the mean $\log _{2}$ titer in groups given $0.75 \mathrm{mg} / \mathrm{kg}(\Delta)$ or $6 \mathrm{mg} / \mathrm{kg}(\Delta)$ of $\mathrm{Cd}$. The dotted line $(\cdots \cdots)$ represents the antibody titer of the control group.

nificantly different from those of control mice.

Effects of $\mathrm{Cd}$ administration in relation to the time of antigen injection were investigated in the following experiments. Mice were given intraperitoneally a single dose of $0.75 \mathrm{mg} / \mathrm{kg}$ or $6 \mathrm{mg} / \mathrm{kg}$ of Cd 1-7 days before or after immunization with $\mathrm{OA}$ in alum on Day 0 . Control mice were given saline on Day 0. They were tested for DTH against OA on Day 7 and bled immediately to determine their anti-OA antibody titers (Fig. 1). Cd administration within 2 days before immunization resulted in a significant $(\mathrm{p}<0.05)$ suppression of the induction of DTH; mice given $0.75 \mathrm{mg} / \mathrm{kg}$ of $\mathrm{Cd}$ on Day -1 , or $6 \mathrm{mg} / \mathrm{kg}$ of Cd on Day -1 or Day -2 developed reduced DTH responses. On the other hand, mice given $\mathrm{Cd}$ earlier than 2 days before immunization, on Day -3 or Day -7 , developed as high levels of DTH as those of control mice. Cd administration within 2 days after immunization had virtually no effect on the induction of DTH; mice developed slightly but not significantly enhanced DTH when injected with Cd on Day 2 after immunization. It was noted that Cd caused a highly significant $(\mathrm{p}<0.001)$ suppression in the expression of already established DTH; the DTH response was not elicited in immune mice given $6 \mathrm{mg} / \mathrm{kg}$ of Cd on Day 7 after immunization, that is, on the day of challenge injection for the elicitation of the DTH response. In contrast to DTH, anti-OA antibody titers were not affected at all regardless of the time of $\mathrm{Cd}$ injection. These results indicate that a single exposure to $\mathrm{Cd}$ caused selective suppression 
of DTH without affecting antibody responses and that this immunosuppressive effect was dependent upon the time of Cd injection.

\section{Suppression by Cadmium of Induction of Memory $T$ Cells and Suppressor T Cells for DTH}

Attempts were made to explain whether effects of $\mathrm{Cd}$ on the induction of memory T-cell and suppressor T-cell activities for DTH were also related to the time of antigen injection for their induction. Mice were primed 7 days previously (on Day -7 ) by either sc injection with a low dose $(1 \mu \mathrm{g})$ of RA-OA or iv injection with a high dose $(500 \mu \mathrm{g})$ of $\mathrm{RA}-\mathrm{OA} . \mathrm{Cd}(6 \mathrm{mg} / \mathrm{kg})$ was administered intraperitoneally 2 days before (on Day -9) or after (on Day -5) the priming. Mice receiving neither priming nor $\mathrm{Cd}$ injection were served as controls. All mice were immunized on Day 0 with OA in alum. Groups of mice primed subcutaneously with $1 \mu \mathrm{g}$ of RA-OA were tested on Day 4 for the memory $\mathrm{T}$-cell activity manifested by an augmented $\mathrm{DTH}$ response against OA. Other groups of mice primed intravenously with $500 \mu \mathrm{g}$ of RA-OA were tested on Day 7 for the suppressor T-cell activity manifested by a depressed DTH response against OA. Figure 2 shows the Cd effects on the memory T-cell activity. Mice primed subcutaneously with $1 \mu \mathrm{g}$ of RA-OA developed augmented DTH upon immunization with OA in alum (Group II). This augmentation of $\mathrm{DTH}$ in primed mice was inhibited when $\mathrm{Cd}$ was injected 2 days before priming (Group III) but not inhibited when injected 2 days after priming (Group IV). Figure 3 shows that Cd effect on the suppressor T-cell activity was similar to that on the memory T-cell activity; mice given $\mathrm{Cd} 2$ days before

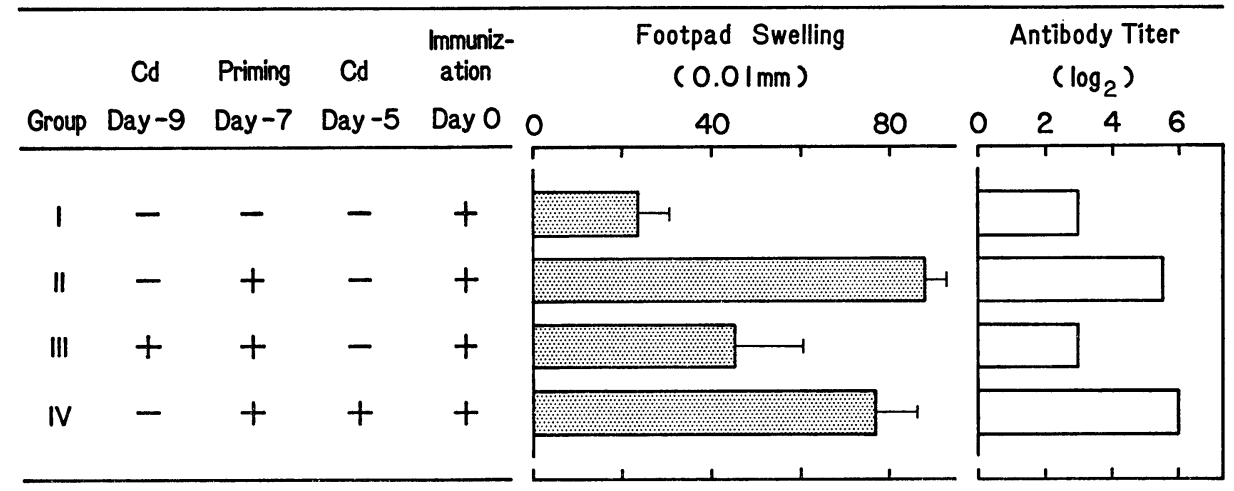

Fig. 2. Effect of Cd on the induction of memory T-cell activity for DTH. Mice were primed subcutaneously with $1 \mu \mathrm{g}$ of RA-OA 7 days previously (on Day -7$)$. Cd $(6 \mathrm{mg} / \mathrm{kg}$ ) was injected intraperitoneally 2 days before (on Day -9) or 2 days after (on Day -5) the priming. All mice were immunized on Day 0 with $10 \mu \mathrm{g}$ of $\mathrm{OA}$ in alum. Memory T-cell activity in primed mice was assessed on Day 4 as an augmented DTH response against OA. Results shown are means ( \pm S.E.) of footpad swelling in groups of 5 mice. Sera were taken immediately after measuring footpad swelling and pooled sera were titrated in duplicate. Each value represents the mean $\log _{2}$ titer. 


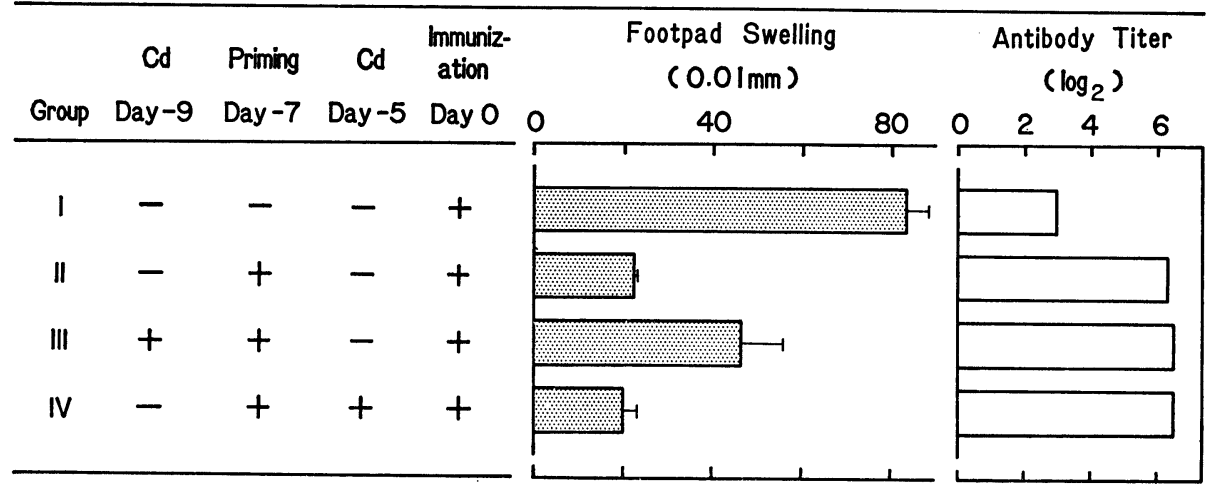

Fig. 3. Effect of Cd on the induction of suppressor T-cell activity for DTH. Mice were primed intravenously with $500 \mu \mathrm{g}$ of RA-OA 7 days previously (on Day -7$)$. Cd $(6 \mathrm{mg} / \mathrm{kg}$ ) was injected intraperitoneally 2 days before or after the priming. All mice were immunized on Day 0 with $10 \mu \mathrm{g}$ of $\mathrm{OA}$ in alum. Suppressor T-cell activity in primed mice was assessed on Day 7 as a depressed DTH response against OA. For other details, see caption to Fig. 2.

iv priming with $500 \mu \mathrm{g}$ of RA-OA showed inhibition of the induction of the suppressor T-cell activity (Group III), although Cd administration 2 days after the priming had no effect on the induction of the suppressive activity (Group IV). Furthermore, carrier effect induced by priming with RA-OA for anti-OA production was also reduced in mice given $\mathrm{Cd} 2$ days before the priming when assessed on Day 5 (Fig. 2) but not on Day 8 (Fig. 3). These results suggest that Cd administration before antigen inhibited effectively the development of augmentative and suppressive $\mathrm{T}$ cells for DTH.

\section{Inability of Cadmium to Suppress DTH-effector T Cells}

Mice previously immunized for DTH failed to develop DTH reactions when given Cd on the day of the challenge injection of DTH-eliciting antigen (Fig. 1). These results led us to ask whether Cd inhibited DTH-effector cells in immune mice or not. The following experiments were made to answer the question. Two groups of 10 mice were immunized with $\mathrm{OA}$ in alum and 7 days later injected intraperitoneally with either $\mathrm{Cd}(6 \mathrm{mg} / \mathrm{kg})$ or saline. Shortly $(3 \mathrm{hr})$ after Cd treatment, five mice from each group were challenged with DTHeliciting antigen into the footpad to assess their ability to develop DTH reactions; the other five mice were served as spleen cell donors. Spleen cells $\left(1.2 \times 10^{7}\right)$ were transferred into the footpad of normal mice along with DTHeliciting antigen to assess their ability to mediate DTH reactions. As a control, normal spleen cells were transferred with the antigen. Table II shows the results. Spleen cells from Cd-treated immune mice induced as high levels of DTH reactions (Group I-A) as those did Cd-nontreated immune mice (Group II-A), when transferred to normal recipient mice. This was also the case in spleen cells from the immune mice which were given $\mathrm{Cd}$ one day before sacrifice 
TABLE II

Effects of Cd on DTH-effector cells in the spleen of immune mice ${ }^{a}$

\begin{tabular}{ccccc}
\hline Group & Immunization & Treatment & $\begin{array}{c}\text { Experimental } \\
\text { procedure }\end{array}$ & $\begin{array}{c}\text { Footpad swelling } \\
(0.01 \mathrm{~mm})\end{array}$ \\
\hline I-A & OA in alum & Cd & Local transfer & $50.3 \pm 2.0$ \\
II-A & OA in alum & Saline & Local transfer & $44.8 \pm 1.2$ \\
III & - & Saline & Local transfer & $22.6 \pm 2.7$ \\
I-B & OA in alum & Cd & F.P. elicitation & $3.6 \pm 1.4$ \\
II-B & OA in alum & Saline & F.P. elicitation & $81.7 \pm 6.8$ \\
\hline
\end{tabular}

a) Two groups of 10 mice were immunized with $10 \mu \mathrm{g}$ of $\mathrm{OA}$ in alum and 7 days later were injected intraperitoneally with either $\mathrm{Cd}(6 \mathrm{mg} / \mathrm{kg})$ (Group I) or saline (Group II). Three hours after Cd treatment, 5 mice from the groups were challenged with DTH-eliciting antigen into the footped (F.P. elicitation) to assess their ability to develop DTH reactions (Groups I-B and II-B). The other 5 mice were served as spleen cell donors. Spleen cells $\left(1.2 \times 10^{7}\right)$ were transferred into the footpad of normal mice with DTH-eliciting antigen (local transfer) to asses their ability to mediate DTH reactions (Groups I-A and II-A). As a control, spleen cells from normal mice given saline $3 \mathrm{hr}$ previously were transferred with the antigen (Group III).

b) Each value represents the mean footpad swelling for groups of 5 mice \pm S. E.

(data not shown). In contrast, no appreciable DTH reactions were elicited in already immunized mice if $\mathrm{Cd}$ was administered to shortly before injection of DTH-eliciting antigen (Group I-B), as described above (Fig. 1). These results indicate that a single exposure of mice to Cd failed to affect already sensitized DTH-effector $\mathrm{T}$ cells, even though it depressed the expression of already established DTH.

\section{Change in Weights of Whole Body, Thymus, and Spleen}

Effects of a single administration of $\mathrm{Cd}$ on whole body weights of mice were examined. Mice were injected intraperitoneally with $6 \mathrm{mg} / \mathrm{kg}$ or $0.75 \mathrm{mg} / \mathrm{kg}$ of Cd on Day 0 and weighed at different intervals. As shown in Fig. 4A, mice given $6 \mathrm{mg} / \mathrm{kg}$ of $\mathrm{Cd}$ grew without death nor decrease in their body weight in a 10-week period when examined every 10 or 20 days. Figure $4 \mathrm{~B}$ shows, however, that a transient but reversible reduction in body weight was caused by $\mathrm{Cd}$ in the first week after its treatment. The acute loss in body weight was maximal on Day 1 in mice given $0.75 \mathrm{mg} / \mathrm{kg}$ of Cd and on Day 2 in mice given $6 \mathrm{mg} / \mathrm{kg}$ of $\mathrm{Cd}$. Then the loss was restored rapidly.

Next, the thymuses and spleens were weighed after injection of $6 \mathrm{mg} / \mathrm{kg}$ of Cd. Figure 5 shows the results. The thymuses of mice given $\mathrm{Cd}$ decreased in weight rapidly and was lightest on Day 2. There was no restoration of the thymic involution by Day 7. In contrast, the spleen weight decreased slightly after Cd injection, increased on Day 1 and was greatest on Day 2. The splenomegaly persisted at least till Day 7 . 


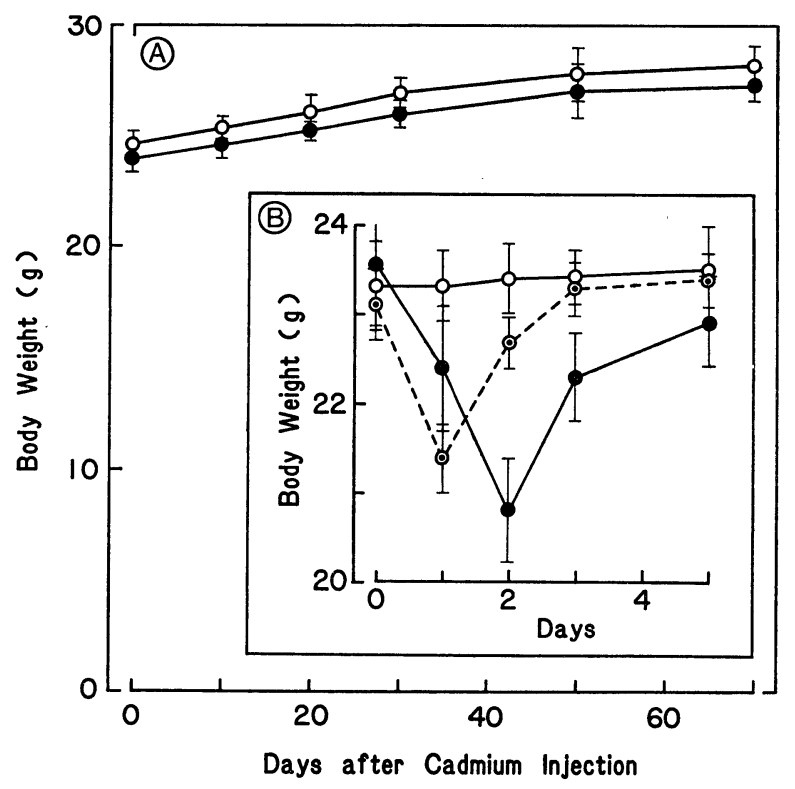

Fig. 4. Effect of a single administration of Cd on whole body weight of mouse. Groups of 10 mice were injected intraperitoneally with either $6 \mathrm{mg} / \mathrm{kg}$ of $\mathrm{Cd}(\bullet), 0.75 \mathrm{mg} / \mathrm{kg}$ of Cd $(\odot)$, or saline $(O)$ on Day 0 , and weighed at different intervals indicated. Each value represents the mean \pm S.E.

\section{Discussion}

We investigated in this study the effects of a single exposure of mice to Cd on the DTH response, T-cell-mediated and monocyte-dependent immunity, against $\mathrm{OA}$. The results presented here indicate that $\mathrm{Cd}$ administration suppressed the induction of certain populations of $T$ lymphocytes mediating or modulating DTH responses; effector $\mathrm{T}$ cells responsible for DTH (Fig. 1), memory $\mathrm{T}$ cells involved in augmentation of DTH (Fig. 2), and suppressor $\mathrm{T}$ cells involved in suppression of DTH (Fig. 3). Furthermore, the induction of helper $\mathrm{T}$ cells for antibody production seemed also to have been suppressed by $\mathrm{Cd}$, because the carrier effect as a function of helper $\mathrm{T}$ cells in mice primed with RA-OA was low in Cd-exposed groups when assessed on Day 5 (Fig. 2) although it was as high in Cd-exposed groups as in control groups when assessed on Day 8 (Fig. 3). This suggests that there is a delay in the induction of helper $\mathrm{T}$ cells. It was also reported that compared to $\mathrm{IgM}$ antibody synthesis, Cd had a much great effect on IgG antibody synthesis (Koller et al., 1975, 1976) which was more dependent on helper $T$ cells than was the IgM response (Anderson, Dresser and Wortis, 1974). Thus, the induction of functional T lymphocytes may be a primary target for Cd. As regards this point, Cd seems to be similar to lead, since it suppressed the induction of primary and secondary 


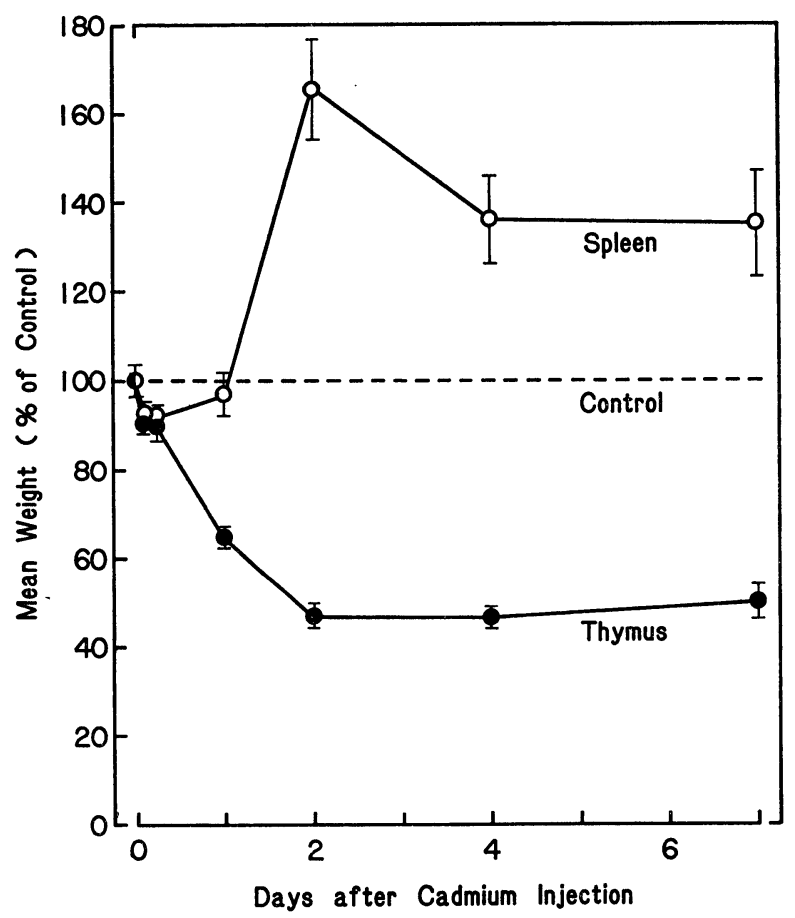

Fig. 5. Effect of a single administration of Cd on the thymus and spleen weights of mouse. Groups of 70 mice were injected intraperitoneally on Day 0 with $6 \mathrm{mg} / \mathrm{kg}$ of Cd or saline as controls. Ten mice from each group were killed on Days $0-7$ to weigh the thymus and spleen. Results are expressed as percentage $( \pm$ S.E.) to the mean weight of control mice given saline.

DTH responses (Mueller et al., 1977), and the IgG response (Koller et al., 1976) against sheep red blood cells. A question arose whether $\mathrm{Cd}$ exposure would suppress also the expression of already established DTH in immune mice. The results presented here clearly show that this is true; no appreciable DTH response were elicited in previously immunized mice given Cd immediately before DTH-eliciting antigen (Fig. 1, Table II). Unexpectedly, however, DTHeffector cells derived from immune donors exposed to $\mathrm{Cd}$ were intact and able to elicit DTH, upon transfer, in normal recipient mice (Table II). Thus, another probable target for Cd may be monocyte known to be involved in the expression of DTH (Crowle, 1975).

Another significant aspect of this study was that the immunosuppression by a single exposure to $\mathrm{Cd}$ was related to the time intervals between Cd treatment and antigenic stimulation. Both the induction and the expression of DTH were suppressed in mice only when Cd was injected within 2 days before immunization or elicitation (Fig. 1, Table II). Earlier than 2 days before antigen injection, Cd had virtually no effects (Fig. 1). Furthermore, DTH responses in mice given $\mathrm{Cd}$ after immunization were similar levels to those in control 
mice (Fig. 1). Cd effect related to time was also the case for the induction of memory $\mathrm{T}$ cells and suppressor $\mathrm{T}$ cells; $\mathrm{Cd}$ administered 2 days before priming with RA-OA for their induction was suppressive but $\mathrm{Cd}$ administered 2 days after the priming was not (Figs. 2 and 3). Since a brief exposure to Cd usually has short-term physiological effects, the suppression of T-cell responsiveness caused by $\mathrm{Cd}$ within 2 days before antigens may reflect indirectly its short-term effects or toxicity. As regards this point, within 2 days $\mathrm{Cd}$ caused in mice thymic involution and splenomegaly (Fig. 5) as well as a transient but reversible reduction in body weight (Fig. 4). In addition, it has been shown that exposure to Cd results in not only splenomegaly (Stowe, Wilson and Goyer, 1972; Gainer, 1973) but also lower lymphocyte and higher neutrophil counts in blood (Stowe et al., 1972). Therefore, Cd may affect the circulation of $\mathrm{T}$ lymphocytes or monocytes in animals and their responsiveness to antigen may be altered indirectly. Consistent with this possibility are the results that DTH-effector $\mathrm{T}$ cells were intact in the spleen of immune hosts exposed to $\mathrm{Cd}$ within 2 days before the elicitation of DTH reactions although the expression of the already established DTH in the hosts was almost completely suppressed by Cd (Table II). Alternatively, the suppression of the expression of DTH might be explained as a result of diuresis, if Cd could be a diuretic like mercury, a well-known diuretic. DTH was estimated by the footpad swelling method which depends on edema formation, and the greatest suppression was observed during the period when the mice receiving Cd transiently lost and regained their body weight (Fig. 4). If such weight loss resulted from diuresis by $\mathrm{Cd}$, profound diuresis and dehydration might prevent the formation of edema in the mouse footpads.

We showed that brief exposure to $\mathrm{Cd}$, an environmental contaminant, produces significant suppression in the induction and the expression of sensitized $T$ lymphocytes in mice. These results add another feature to the role of environmental contaminants in public health, suggesting that they suppress not only the induction of T-cell immunity against infective agents, but also the expression of the immunity against subsequent challenges with parasites even though the resistance has already been established in the host by vaccination or natural infection. Although short-term effects of a single exposure to Cd were assessed in this study, continuous exposure to the metal would produce long-lasting effects on cell-mediated immunity as reported on humoral antibody responses after discontinuance of exposure (Koller et al., 1975). Many of its acute and chronic effects, direct or indirect ones, require further investigation to see their significance on human health.

\section{ACKNowledgements}

We wish to thank Drs. B. Simizu, M. Otokawa and M. Sugimoto for helpful discussions, Mr. K. Yaginuma for technical assistance, Mrs. K. Miyanomae for animal care, and Miss M. Kimura for assistance in preparation of the manuscript. 


\section{REFERENCES}

Anderson, H. R., Dresser, D. W. and Wortis, H. H. (1974): The relationship between the immunoglobulin class of B-cells precursors and the degree of synergism obtained from the presence of T-cell. Clin. Exptl. Immunol., 16, 393-400.

Christensen, F. C. And Olson, E. C. (1957): Cadmium poisoning. Arch. Ind. Hlth, 16, 8-15.

Crowle, A. J. (1975): Delayed hypersensitivity in the mouse. Adv. Immunol., 20, 197-264.

Exon, J. H., Koller, L. D. AND Kerkvliet, N. I. (1979): Lead-cadmium interaction: Effects on viral-induced mortality and tissue residues in mice. Arch. Environ. Hlth, 34, 469-475.

Flick, D. F., Kraybill, H. F. ANd Dimitroff, J. M. (1971): Toxic effects of cadmium. Environ. Res., 4, 71-85.

GaIneR, J. H. (1973): Activation of the Rauscher leukemia virus by metals. J. Natl. Cancer Inst., 51, 609-613.

Jones, R. H., Williams, R. L. And Jones, A. M. (1971): Effects of heavy metal on the immune response Preliminary findings for cadmium in rats. Proc. Soc. Exptl. Biol. Med., 137, 12311236.

Kojima, A., Tamura, S.-I. And Egashira, Y. (1979a): Regulatory mechanism of delayed-type hypersensitivity in mice. I. Properties of memory cells and suppressor cells for delayed-type hypersensitivity against ovalbumin. Cell. Immunol., 45, 61-73.

Kojima, A., Tamura, S.-I. and Egashira, Y. (1979b): Preferential induction of memory T cells for delayed-type hypersensitivity with reduced and alkylated human serum albumin in mice. Immunology, 38, 717-725.

Koller, L. D. (1973): Immunosuppression produced by lead, cadmium, and mercury. Amer. J. Vet. Res., 34, 1457-1458.

Koller, L. D., Exon, J. H. And Roan, J. G. (1975): Antibody suppression by cadmium. Arch. Environ. Hlth, 30, 598-601.

Koller, L. D., Exon, J. H. ANd RoAn, J. G. (1976): Humoral antibody response in mice after single dose exposure to lead or cadmium. Proc. Soc. Exptl. Biol. Med., 151, 339-342.

Mueller, S., Gillert, K.-E., Krause, C., Gross, U., L'Age-Stehr, J. And Diamantstein, T. (1977): Suppression of delayed type hypersensitivity of mice by lead. Experientia, 33, 667-668.

Stowe, H. D., Wilson, M. AND Goyer, R. A. (1972): Clinical and morphologic effects of oral cadmium toxicity in rabbits. Arch. Pathol., 94, 389-405.

Suzuki, M., Simizu, B., Yabe, S., Oya, A. ANo Seto, H. (1981): Effect of cadmium on Japanese encephalitis virus injection in mice. 1. Acute and single dose exposure experiment. Toxicol. Lett., in press.

Tamura, S.-I., Kojima, A. AND Egashira, Y. (1980): Regulatory mechanism of delayed-type hypersensitivity in mice. II. Effect of suppressor cells on the development of memory cells for delayed-type hypersensitivity. Cell. Immunol., 51, 250-261.

Tamura, S.-I., Kojima, A. ANd EgAshira, Y. (1981): Regulatory mechanism of delayed-type hypersensitivity in mice. II. In vitro analyses of memory $\mathrm{T}$ cells involved in augmentation of DTH responses. Microbiol. Immunol., 25, 595-607.

Tamura, S.-I., Kurata, T., Sugimoto, M. and Egashira, Y. (1973): Cellular and humoral immune responses in mice. I. Development of delayed-type footpad swelling against sheep erythrocytes and its suppression by intraperitoneal administration of the antigen. Japan. J. Med. Sci. Biol., 26, 161-168. 